Journal of Economics and Behavioral Studies

Vol. 2, No. 5, pp. 186-190, May 2011

\title{
Retailer's Perspective on Support Services Offered by Vembanad White Cement
}

\author{
Satya S \\ Acharya Institute of Technology, Soldevanahalli, Bangalore, India \\ ss.manuscript@gmail.com
}

\begin{abstract}
Buying behavior of consumers in Cement industry is greatly influenced by retailers as they are the last point in the distribution channel and have a direct understanding of consumer's requirements. The retailers experience firsthand reactions of customers on product, services and quality assessments. In practice, it is very easy for a retailer to impress on the customer with a change in brand even at the very last moment. Because cement retailing is not exclusive and variety of competitive brands is available in the same outlet, it is important that the manufacturing company take great efforts to satisfy the retailers and keep their "support service levels" very high. The research through a field survey explores retailer's perspective on support services offered by Vembanad White Cement. Suggestions are given to the company on increasing support services to the retailers through efficient complaint handling, credits and processing speed to enable smooth transactions between the retailers and the customers. Retailer's satisfaction would influence buying behavior of end customers in a positive way. Proactive and personal approach from the company will make the retailers take interest to pass positive feedbacks to the consumers on product and its quality. In the buying process, recommendations from the retailers are the final step in sealing sales with the customers. Hence it is important to understand the retailer's suggestions for improvements in service levels. Implementing these improvements will not only promote positive attitude of the retailers, in turn, it will also pass on as positive word of mouth to the customers encouraging larger client base and profits to the company.
\end{abstract}

Key Words: Cement retail, Support services, buying decision-making.

\section{Introduction}

Retailers are traders who buy goods from wholesalers or sometimes directly from producers and sell them to consumers. They generally operate through a retail outlet and sell to the end consumers. Since the retailers are the last point in the distribution channel, they see the reaction of the consumers firsthand and know their requirement more than anyone else knows. Because cement retailing is not exclusive and a variety of competitive brands is available in the same outlet it is important that the company is in constant mode to satisfy the retailers through flawless support service. This will in turn make the retailers take interest to pass positive feedbacks to the consumers and impact decision-making process of end consumers. Recommendations from the retailers are the final step in sealing sales not only in cement industry but also in many other industries. Retailers have potential to affect change in the consumption pattern of the consumers for consumers rely heavily on recommendations made by the sales men on product quality. Customers cross check the opinions of other customers through the retailers. Retailers can significantly affect change to consumer decision making, as they are located in key position between suppliers and consumers. On one hand being in direct contact with the consumers they exert influence on consumers through their counter sales person, and on the other hand, they reach out to suppliers and gain advantage based on their strength and capacity to reach out to customers. In a way, they act as gatekeepers, determining which brands are to be offered and how they should be marketed. Understanding the importance of service support to execute sales at the retailer's level, this study aims to find out the sales support offered by Vembanad White Cement to its retailers and the perspectives of the retailers on the support services.

\section{Company and Product Profile}

Taravancore Cement Limited (TCL) is one of the oldest cement manufacturing public sector undertaking, functioning in the state of Kerala since 1946. The company was promoted by the state of Travancore, which 
was in Tamil Nadu during the 1950s. Later the Government of Kerala acquired the company with a share of 51.33\% and about 33.33\% share with the Super Pharma Private Ltd., which belongs to the company group. The share of the company has been listed in the stock exchange of Cochin \& Chennai. The company was promoted by M/s Essel Ltd, Mumbai and Technology tie up was made with M/s F.L Smith \& Co., Denmark. TCL is one of the first projects making cement companies in Kerala. TCL is the only public sector (Kerala Government undertaking), which manufactures and market white cement \& cement paints. Vembanad White Cement (VWC) is a world class product manufactured from rare raw material consistent in purity backed by technology and machinery from M/S F.L. Smith \& Co. Denmark. TCL manufactures the best white cement in the country and its quality is at par with that of the best available in the world market. This can be attributed to the fact that Vembanad white cement is manufactured using lime shell, white clay, white silica, sand and crystal gypsum. White cement is extensively used in the manufacturing of mosaic tiles, artistic molding and for outdoor decorations. TCL is one of the only two companies in the world manufacturing White Cement from a raw material other than conventional limestone.

\section{Literature Review}

Nicole and Raman (2007) through their study established that store employees play a very critical role in the retailing sector. The study was done through a quasi experimental design and hypothesis was tested through regression model to prove that "sales in stores is positively correlated with the change in store manager incentive plan" and "store shrinkage that is reduction in store inventory levels and firms advertising budget is positively correlated with changes in store manager incentive plans". Findings from this study revealed that changes in incentive plans of store managers had positive effect on store sales and store shrinkage. A 13 per cent increase was noticed in sales of goods with a hike in incentive plans. Adding the gains from shrinkage the gross margin profit were 36 per cent. These findings are among the first to link incentives to retailers profits and to quantify the impact of store manager's incentive on retail performance. Though incentive to a store manager can be viewed as a retailer's domain, the manufacturing company can offer better incentives to the retailers encouraging the sales men in turn to get more for his effort in influencing consumer decision making. Any retail outlet operates within the framework of the community. The people who are the members of the community, the demographic details of the neighbors namely family income, family life cycle has an effect on the performance of the retail store. In another study by Kean et al. (1998), the strength of relationship was tested between retailer performances, community characteristics, business environment and competitive strategies. Apart from testing the strength of relationship among variables, the nature and effect of relationship among variables and contributing factor of any of the variable to retail performance was tested. Data for the study were collected through electronic survey and mailed questionnaire. The final analysis was done with 456 retailers from 12 rural areas in the US. After a stratified sample community stores, general merchandise stores, apparel and accessory stores, miscellaneous stores, building material stores and furniture store were considered for the study. Study revealed that there was significant relationship between community measures of market size, change in market size and purchasing power, use of competitive strategies and the business environment. It was also noticed that change in population and the length of time a retail store was in the community influenced strategy selection. In short, the study established that business environment was an indicator of community retail performance.

Many innovations are happening in the retail sector in India too. A report on Strategies for rural marketing by Rajarshi, Narasimham, Ashish, and Kartik (2006) highlight that to achieve deeper penetrations to the vast rural market in India Hindustan Lever Limited, a subsidiary of Unilever, the largest FMCG company started innovative retailing through project Shakti where in women were roped in as sales/ retailers. Houses were used and point of purchase promotional display was done in house hold window. Retailing through women had four pronged effect which includes income generation, improved quality of life, community empowerment through relevant information on their portals and literacy programs. Currently 15,000 Shakti retailer entrepreneurs in 61,000 villages across 12 states promote Hindustan Lever products and penetrate the rural Indian market. Retail Value Chain actors play an important role in shifting their customers' behavior and lifestyles towards sustainable consumption. In order to cope with this joint responsibility retailers as well as manufacturers are in need of a collective strategy. Such efforts will make it possible to influence 
effectively the existing consumption patterns while successfully promoting sustainable production along the supply chain (Burcu, 2009).

The cement sector retail sales give a clear indication of the growth in the GDP. If the growth is robust, the infrastructural sector will flourish and cement is one of the main products that constitute the infrastructural sector. Retail sales are clear indications to the company as to what their future or the next quarter is going to look like. The strength of a cash rich company rests on amount of retail sales that is being generated in the market. "The Retail Sales report is an important leading indicator because it gives a glimpse into what the upcoming quarterly Gross Domestic Product (GDP) that gives an idea of how fast the economy is growing or shrinking or might look like. Consumers make up approximately 70 percent of the GDP. So if consumers are spending their money, GDP will probably show that the economy is growing, and vice versa. The Retail Sales report provides a t crucial glimpse into how individual retailers will most likely perform in the future. When retail sales are up, it is an indication to the company that their product is growing and the company is leading to profits. Conversely, when retail sales are down, earnings and profits at most indicate difficult economic times". In most business, the individual retailer plays a pivotal role in the marketing effort. It is the retailer interaction that gives rise to a sale. So, the quality of this interaction is a key determinant of marketing success. It will determine the extent to which the effort and expenditure incurred on promotion is translated into sales. Even after generating good consumer preference for a brand through effective advertising and promotion, a firm may fail to generate sales, if the retailer fails to convince the customer at the point of purchase. A retail outlet is not a mere place- the interaction and the process that takes place between the retailer and the customer plays a pivotal role in market penetration, market development, merchandising and promotion. As competition gets tougher it is the retailer who provides the cutting edge as he is the only person in the supply chain who has direct contact with the client.

While earlier there were just a few brands in the market for any product category, in recent years their number has swollen up. This has put the retailer in the forefront of the marketing strategies of companies. It can be said that today, the marketing success or failure of a product is decided to a large extent at the retailer's level. Due to the advancement in science and technology more and more competitors emerged in the market with new variety of products. So it has become obligatory from the part of existing manufacturers to maintain a cordial and satisfactory relationship with retailers, wholesale, dealers and consumers. Retailers require a variety of support services to carry on their business. The most important support service for the retailers is to be provided with optimal quantity of stocks at all times. Keeping the supply chain vibrant and efficient is very important for smooth sales at the retailer's end. Secondly, manufacturers can support retailers with special price offers for bulk purchases; this is another aspect of service support that can be offered to generate sales. Advertising support is yet another support that is of immense value to the retailers.

\section{Method of Study}

A survey was undertaken with 50 retailers in Kottayam District, Kerala India. The district of Kottayam was broadly divided into North, South, East and West and 10 retailers were selected from the North based on the visibility and quantum of business they do. Similarly, 15 retailers were chosen from South, 12 from East and 13 from West Kottyam to complete the study. A semi-structured questionnaire was prepared with 15 questions and the researcher administered the questionnaire personally. Five to seven retailers were met on a day and the data collection took two weeks to complete. Three questions were set to elicit answers on the identity of the retailer and 12 questions were set to elicit answers for the set objectives. A combination of multiple choices, rating scale questions were asked, while the last question namely "suggestions" was left as an open ended question.

\section{Findings and Discussion}

Initial questions probed about the number of years the retailers has been in business with the company, perspective of retailers on the pricing of the product, the retailer's spread and stock availability. After these aspects, questions were asked about the sales support that the retailer gets through company, the advertising support for sales, mass media promotions for the product, grievance handling for specific cases. Findings revealed that 40 per cent of the retailers are stocking the product for more than 15 years and 22 per cent of 
them are dealing with VWC for less than 5 years. Increasing dealer network and retailer network is vital to maintain good distribution levels, healthy product penetration and robust service levels for the manufacturer. Since only 22 per cent of the retailers are new that is within five years of dealing with VWC effort from the manufacturer to add new retailers, especially when cities are growing at alarming rate progressing into new territories and boundaries is advised.

All 50 respondents who were studied stocked VMC and the next most stocked brand in the category was Birla White Cement. To a question on why a particular brand is preferred, it was observed that 94 percent of the customers prefer the brand for quality, where as 6 per cent consider price an essential factor for purchase of the product. To find out the perspective of retailers on the price point of VMC, it was observed that 90 per cent of the retailers felt that the price was comparatively high. It was surprising to note that though 90 per cent of retailers felt that price of VMC was high compared to the competitive brands, 86 per cent of them felt that customers were not switching brands because of higher prices but gave more weight age to quality and endurance of the cement. So the market is more conscious to quality than price, and it is binding on the company to maintain their quality to retail and enhance the customer base in this segment. Spread of retailers and the distance between retailers store is an important factor to boost sales figures. Today customers are not willing to travel a distance to get the brand they require. If retailers are situated in close proximity, the chances of losing a customer are remote. Hence, the study focused on finding out the distance between the retailers stocking VWC. Distribution net work revealed that 58 per cent of the retailers are situated between 5 to 10 kilometers distance between them and about 12 per cent of the retailers are situated between 10 to 15 kilometers. The company can aim to maintain 7 to 8 kilometers distance between retailers by increasing the number of retail chain. This way the cost incurred by the customer on transportation will also decrease. The proximity will also lead to time efficiency in terms of delivery schedules and service levels.

Probing on wholesaler retailer relationship, the study revealed that 90 per cent of the retailer opinion that good relationship are maintained with the nearest dealer and 10 per cent have neutral opinion on this aspect. It is encouraging to see that none of the respondents had disagreed or strongly disagreed about good business relationship between them. It is heartening that there are no disputes, rivalry, or unhealthy undercutting and competition existing in the market, which is alarming for the brand and the manufacturer. To gain retailers perspective on movement of stock and availability of stock at all seasons without bottleneck in the channel, questions were posted on the pull from the market in terms of movements of stock. 70 per cent of the retailers had heavy sales during July and September, and another 22 per cent said the movement of the product was brisk during January and March. This pattern is in tune with the monsoon season. Monsoon in Kerala set during end May and heavy rain is experienced till the end of June. Virtually no construction work is undertaken during this season but for few repairs and distress maintenance. Stock positions hence will have to be prepared for quick distribution soon after the monsoon. While 16 per cent said "yes" a whopping, 84 per cent maintained "no" to the question on retailer's satisfaction towards "sales support" activities from the company. This aspect need to be addressed as the retailers are gaining importance in the supply chain in all product categories. Gone are the days when manufacturer had the upper hand and the muscle in the supply chain, today the strength and enthusiasm the retailers makes or mars a brand. Sales conversion actually happens at the retailers point and dissatisfied retailers can convert the sales to other brands even when customers ask for a particular brand.

First and foremost, the evoked sets of alternative products are similar in most of the features and quality. Secondly, the customers always tend to ask for suggestion from the retailer before concluding the sale. If the retailer suggests that there is a new product, priced smartly with same product features, the customers tend to listen to the retailer, as they sincerely believe that his expertise in the field is high, as he is dealing with similar products for years. It is imperative that the company takes efforts to find out what kind of sales support is needed and do everything in their managerial capacity to render the support to the retailers. Offering good sales support through advertisement is the obligation of the company towards trade and retailers. The retailers were asked to give their opinion on the "sales promotions" activities initiated by the company. It was observed that 68 per cent of the retailers took a neutral stand and only 8 per cent agreed that sales promotional support rendered by the company was good. Since "sales promotion" is a part of "sales support" activity and "sales support" activity was rated very low by the retailers it is not surprising that the 
retailers have also rated promotional schemes offered by the company as low. Sales incentives, volume incentives, cash incentives, and other forms of sales support through mass media are important for the retailers to feel the pull from the market forces.

As far as sales support through mass media is concerned, it was observed that 76 per cent of the retailers felt that the company gave advertising support to the product through mass media. 92 per cent of the retailer's felt that the effectiveness of the advertisement is good and brings results through good sales. 56 per cent of the retailers felt that transit sign boards were effective medium where as 20 per cent felt that print medium was advisable and only 6 per cent felt that radio is the right choice to effectively reach the target audience for white cement. So, what is evident is that the retailers want sales support through other aspects namely processing time for orders, delivery schedules, credit facilities, complaint handling to name a few. The next set of questions was based on eliciting answers on these aspects of sales support from the company to the retailer. While 82 per cent had neutral opinion on the profit margins set for the retailers, only 6 per cent felt that the margins were good. There is a scope for introspection here. The company must see if they are "on power" with the competition on sales margins and if sales margins cannot be improved on a blanket to all the retailers, at least incentives on target achievement can be introduced to make the retailers more competitive. Handling grievance on product returns, bills, process of delivery are another important aspect of "sales support" to the retailer. While 72 per cent had no complaints on grievance handling, 28 per cent of the retailers were not satisfied with the company on handling their grievances. Complaint handling especially when it comes to exchange of bad stock, pilferage etc causes a lot of trauma to the retailer. On one hand the retailer's sales has not taken place properly and customers are unhappy and on the other hand, the money is locked on stock, which is occupying the go-down space which is scarce. Time for processing order is another important factor in "sales support". 64 per cent of the retailers feel that it is neither too fast nor too slow and is based on the order quantity and climatic conditions. During unexpected rains and wet weather, the orders are delayed due to transportation, road conditions and availability of labor for loading and unloading. 80 per cent of the retailers have a neutral opinion on the discounts offered pointing out that the company is on power with its competition and is neither offering too much to please the retailers not giving too less to the retailers because of their market leader's position. Thus a neutral opinion here is not alarming.

\section{Conclusion}

A study on retailer's perspective towards VMC was conducted. The scope of the study was restricted to Kottayam. 50 retailers were chosen and a field survey was conducted through structured questionnaire. Raw data was analyzed the results and discussions are reported to get better insights of what the retailers want from the company to get more effective in the market. Though the company is rated high for maintaining good relationship and the retailers are very happy about the affectivity of advertising, there is scope for improvement in processing time and grievance handling by the company. Credit facility to the retailer is another aspect that can be reworked to enable good support to the retailers.

\section{Reference}

Burcu, T. (2009) UNEP ISETAC Lifestyle Initiative Project, Fostering and Communicating Prodcut Chain Information. Retrieved from http://www.scp-centre.org/projects/projects/basic-projects-data/03unepsetac-life-cycle-initiative-project.html.

Kean, R. K. Luann, G. Larry, L. Cynthia, J. Bastowshoop, L. J. Brenda, S. (1998). Effect of Community Characteristics, Business Environment and Competitive Strategies on Rural Retail Business Performance. Journal of Small Business Management, 36(2): 45-57.

Nicole, De H., Raman, A. (2007). Store Manager Incentive Design and Retail Performance: An Exploratory Investigation. Manufacturing and Service Operations Management, 9 (4): 518-533

Rajarshi, R., Narasimham, M. L., Ashish, G., Kartik, V. (2006) Project Report by Department of Humanities and Social Sciences, IIT, Bombay. Strategies for Rural Marketing Retrieved from http://www.it.iitb.ac.in/ deepak/deepak/courses/eco/pdf/strategies_for_rural_marketing_by_an_orga nization.pdf. 